\title{
Minutes of the August 28, 2013, APSA Council Meeting
}

\section{PLACE AND ATTENDANCE}

Chicago Hilton, Chicago, IL

Present: John Aldrich, Jonathan Benjamin-Alvarado, Catherine Boone, Michael Brintnall, Gretchen G. Casper, Brian F. Crisp, Page Fortna, Archon Fung, John Green, Paul Gronke, Ange-Marie Hancock, Nancy Hirschmann, Juan Carlos Huerta, Jeffrey Isaac, John Ishiyama, Junko Kato, David A. Lake, Taeku Lee, Jane Mansbridge, Kenneth J. Meier, Joanne Miller, Todd C. Shaw, AnneMarie Slaughter, Kathleen Thelen, Kenneth D. Wald, Stephen M. Walt, Angelia R. Wilson.

APSA Staff Present: Jeff Biggs, Regina Chavis, Jennifer Diascro, Jonathan Gilad, Rob Hauck (Editor of PS), Polly Karpowicz, Liane Pinero-Kluge, Kimberly Mealy, Steven Rathgeb Smith, Betsy Super, Lauren West.

Guests: Jennifer Hochschild and Kaare Strom

\section{CALL TO ORDER}

The regular meeting of the APSA Council on Wednesday, August 28, 2013 was called to order at 8:30 a.m. by President Mansbridge.

\section{WELCOME AND REPORT OF THE PRESIDENT}

President Jane Mansbridge opened proceedings and asked for each council member and APSA staff member to introduce themselves.

President Mansbridge thanked all the outgoing council members including Hanes Walton, she also thanked Michael Brintnall particularly for his work on the teaching and learning conference and the Africa Programs. She invited the council members to the opening reception at 8:45 p.m. where a small program will be held to honor Michael Brintnall. The council applauded his work. President Mansbridge then welcomed the new Executive Director Steven Rathgeb Smith who would assume his position following the council meeting.

President Mansbridge mentioned how much she appreciated the council members and the various committees who have worked so hard this past year. APSA works through the sweat on the brow of people who have other things they have to do. She mentioned all the meetings that she spoke at as president of the association, including northeast, southern, and Moscow and that President-elect Aldrich spoke at the British groups. She said that the highlight of her tenure was talking at the Teaching and Learning Conference, she was particularly moved by how much that group has created a sense of community.

President Mansbridge told the council that she hopes to have a final report on her Task Force in December. Her Task Force would bring together what we know about negotiation and agreement and its importance in this time when Congress's ability to negotiate is breaking down. Originally the Task Force was supposed to have three groups, with APSA paying for one of them, in the end he Task Force is now comprised of six groups, and partially funded by NSF. When the NSF could no longer support the work of the association, the Task Force found universities to help with accommodations, and met only in the Northwest to avoid additional travel costs. She also mentioned the loss of NSF funding and that she trusts Steven Smith will work to reverse that.

\section{CONSENT AGENDA AND COMMITTEE APPOINTMENTS}

Executive director Michael Brintnall outlined that the consent agenda includes the standing and award committee appointments, the Council minutes, and anything else the council wants to add.

President Mansbridge motioned to "approve the committee appointments." Council member Hancock seconded, and the appointments were approved unanimously.

\section{REPORT OF THE EXECUTIVE DIRECTOR}

Executive Director Brintnall thanked the council for all their work and the opportunity to serve the association. Members of the council expressed their thanks to Michael and mentioned some small vignettes about his tenure.

\section{FINANCE REPORT}

APSA Finance Director Regina Chavis delivered the finance report. She directed the council's attention to page 31-32 for the budget snapshot. She stated that overall the financial condition is good. A couple par- ticulars including organized section bank accounts, increase in investments (Cambridge, etc), and increase in APSA property value (due to HVAC and other improvements) where mentioned. Total liabilities have gone up a bit: 2012 Cambridge outstanding liability swap value (renovation induced mortgage rates). Slight increase of Annual Meeting revenue. Total fund balance increase slightly (15\%?) (including organized section). Mrs. Chavis directed the council to page 33: statement of operating activities and programs. Revenue expenses in line with expectations with total of $\$ 3.2$ million. Chavis also said that APSA presented in GAT format which does not include balances. Chavis also explained that the loss statement which does not include annual meeting that is ongoing will come around and that APSA is expecting a positive bottom line at the end of the year.

Taeku Lee asked for final assessment on cancelling the meeting last year. Chavis responded that there was no loss since the insurance covered everything. The AV expense wasn't turned in on time but it will come through this year. There is no hotel rebate since the meeting was cancelled.

APSA Treasurer Jonathan BenjaminAlvarado thanked APSA and especially Regina Chavis and Michael Brintnall who kept this whole process (reimbursement from the insurance due to the cancellation) professional and transparent.

Kathleen Thelen asked how APSA has compensated for an erosion in membership and therefore dues? Chavis pointed out that we are working as a team to revitalize membership and specifically focusing on retention and recruitment, but APSA has been increasing its dues steadily which helped compensate for the loss in revenue. She further said that these measures cannot address the future of the association. Mrs. Chavis then asked if the council could approve the budget.

Council member Todd Shaw asked how the benefit structure for APSA has changed with the implementation of Obamacare. Chavis responded that that APSA has a very good price rate, but that we have adjusted some deductible for staff and are keeping constant on it to take care of the APSA staff. 
The budget was approved by the council unanimously.

\section{ANNUAL MEETING UPDATE}

On behalf of Lauren West, Jonathan Gilad from the APSA staff informed the council that APSA is expecting around 6,00o attendees at the Annual Meeting and on target for one of our largest meetings.

\section{SECTION JOURNAL REPORT}

APSA Director of Communications and Publishing Polly Karpowicz asked for the council approval of the for the section journal. The journal is to begin in 2015 and published by Cambridge. APSA policy is currently that the contract is reviewed by the executive director and that both Michael Brintnall and Steven Smith have approved it. Brintnall announced that it has complied with all the regulations. President Mansbridge motioned to approve the journals, seconded by Council member Brian Crisp.

The council approved the motion unanimously.

Jeffrey Isaac asked to move his board nomination after $P S$. No objection was raised.

\section{APSR REPORT}

American Political Science Review Editor John Ishiyama said that he just wanted to highlight the transition process and thanked previous editors who made the transitions. They have received over 7,00o submissions and over 800 were new submissions which totals an increase in submissions of $18-19 \%$. This is the highest number of submission. Meanwhile, the editorial team has reduced turn around time by $40 \%$. Right now the rate is about 41 days from first submission to first revision-previously it was 61 days. They were supposed to submit a study on reviewer fatigue, but it is taking longer than expected. We think there is some kind of fatigue, $1 / 3$ said they are asked to review a lot more $1 / 3$ because they are becoming provost or something similar, and the rest had personal reasons or just didn't want to review some of those articles. We hope to finish their study by next year or in Chicago.

Ishiyama also reported a slight increase in comparative politics, decreased number for American politics, but an increased international politics which, was a goal of the new team. Formal quantitative and formal qualitative have been consistent. In terms of data, his team is keeping data on gender and international submissions, which they calculate on their own. They also have data what portion of the authors are women or international. Currently their desk rejection is about $20 \%$. Invitation to revisit is high at 8.9\% comparable to the UCLA team which was $8.2 \%$. The acceptance rates have risen in IR (as other fields have been consistent with previous years). In terms of production, they are back on schedule with production.

Ishiyama pointed out that he intends to take greater role in promoting the DART's initiative. He also recognized Michael Marvin and Cambridge, who have made great efforts to make the review more public and that they have been cooperating with the Monkey Cage.

Steven Smith asked what is the backlog in print publication? John Ishiyama responded that they don't have any. Currently they are running close to one issue, but not ahead. They have also been trying to increase the size of the Review so that would eat up of backlog.

Steven Smith asked if this has this increased the number of pages? John Ishiyma responded that it has increased it by 100 pages but still under the amount allotted by Cambridge. He also said that their second goal is to increase the size of the Review.

Angelia Wilson asked if there is some way that we can receive a slightly more detailed analysis from all three journals, not just on gender, but what kind of submissions and acceptance for those outside the US? John Ishiyama replied that he intends to be able to report on those issues, but currently they do this kind of data by hand.

The council then asked about data collection legality issues and logistical questions. There also some discussion regarding editorial manager and possibly just using Lexus Nexus. Council member Anne-Marie Slaughter asked if APSR could start the practice of putting up publicly accessible abstracts of the articles. Ishiyama responded that they are trying to work on diversity and changing perceptions of APSR, but they are worried that people are not submitting articles since they believe they won't be published anyway. He also mentioned that they are trying to work on the public presence, and highlighted one instant where an APSR article was quoted in Time Magazine but they didn't credit the APSR. They have contacted Time and hope that it won't happen again. Ishiyama also responded to President-elect Aldrich that they contact various news sections to let them know about articles in APSR. John Ishiyama then asked for some time to study the reviewer and perception process and APSR and report back for to council.

\section{PERSPECTIVES BOARD}

\section{NOMINATION}

Perspectives on Politics Editor Jeffrey Isaac said that his office experienced a transition with book editor Margot Morgan leaving, and James Moskowitiz has helped along with the APSA staff. The December issue is getting ready to go to print, and they have a substantial queue of articles that they are working through.

We publish a statement of mission and procedures in the beginning of the journal, and we added this statement of the importance of books to political science to that statement. He mentioned that there eight people nominated to expand the Perspectives board. Isaac said that all of these nominees have contributed as authors; reviews etc. and are active contributors.

Benjamin-Alvarado motioned to approve the nominees, seconded by Catherine Boone.

The council unanimously adopted the recommendations. Marie-Slaughter abstained from voting since she was one of the nominees.

Kathleen Thelen then praised Perspectives as the only journal that highlights books for the membership.

\section{PS REPORT}

$P S$ Editor Rob Hauck said that the focus of $P S$ is presenting political science, acting as a record of the association, and publishing articles on teaching. Furthermore $2 / 3$ of the readership survey responded that they are satisfied with the journal and that the journal has made a remarkable stab at diversity, institution, rank, ethnic, and international background. He also said that this would be his last report as PS editor and probably any $P S$ editor. He mentioned discomfort with the discussion of $P S$ moving forward because he is leaving. Hauck also mentioned the four missions to the association in regards to publishing: scholarship, enhancing scholarship, teaching, and publicity. $P S$ is the only one that covers all four, and it is an unusual assumption that since it does all four, it can't do them well. He concluded that we need data to support that claim.

Council member Nancy Herchsmann mentioned that over the years the balance has shifted from teaching to scholarship, and maybe a more proactive inclusion of these people would be helpful?

Hauck responded that $P S$ has always tried to contact and mine that field for articles. Furthermore, his team was not increasing research at the cost of teaching. In fact, he pointed out they have a section of teaching 
so it would not be lost. The journal has been and continues to be committed to teaching and learning.

Jeffrey Isaac then went on to say that he admires what Rob Hauck had just said.

In September 2012, the APSA Council mandated the creation of a Publications Planning Ad Hoc Committee. The committee was constituted in October 2012, met twice in person at the APSA office in January and June 2013, and, as noted in its August 2013 report to the APSA Council, engaged in extensive e-mail and telephone conversations.

Jennifer Hochschild (Harvard University) reported as chair of the Planning Committee that included: Larry Bartels (Vanderbilt University), Simone Chambers (University of Toronto), Derrick Cogburn (American University), Eric Crahan (Princeton University Press), Yoshiko Herrera (University of Wisconsin-Madison), Macaartan Humphreys (Columbia University), Karen Kedrowski (Winthrop University), Marc Lynch (George Washington University), Rahsaan Maxwell (University of Massachusetts, Amherst), Ricardo Ramirez (University of Notre Dame), and Kaare Strom (University of CaliforniaSan Diego). She offered brief introductory comments to the council, thanked the members of the committee, and thanked PS: Political Science \& Politics editor Robert Hauck for his comments that preceded her own report. Hauck expressed chagrin that the discussion of $P S$ was precipitated by his expected 2014 departure. He noted that over the twenty years of his editorship there had been no council complaints. $P S$, in his estimate, was the only journal that covers all of the four objectives outlined in the Planning Committee report, and wondered how this could be improved "by taking PS apart and farming them out." He added that PS was constantly changing and cautioned against "precipitous change."

Hochschild noted that Planning Committee report was not a blueprint and was not intended to be a critique of current APSA journal editorships. She stated that the Committee's mandate involved four missions or purposes of APSA publications: (1) creation and use of scholarship, (2) enhancement of teaching, (3) career support and development, and (4) public visibility and impact. The written report indicated that "the APSA could continue doing what it is now doing without warranting any serious dismay. Nevertheless, it can do better; technological innovations for research, teaching, and communication are upon us, goals are expanding, and the APSA should not continue publishing only as it has done for some decades. She noted two reports on publishing in economics. Perhaps the most critical gap lies in the arena of public and government engagement. Publications are not all that is needed, but they should be an important element of that engagement." In her oral presentation, she emphasized that there are some real economic tradeoffs in a number of the suggestions made by the report.

She pointed out that the second half of the report focuses on the process of publication for which the association probably doesn't have a sufficiently systematic survey. Hochschild referred to the written report for several oral observations to the Council: the journals relationship to blogs could be a full-time staff responsibility; integrating research on teaching and learning could turn to an existing journal such as the Journal of Political Science Education which is not under the Cambridge umbrella (she noted that the committee didn't follow up on this because there was no attention to other section journals), lead to the creation of a new journal or continue with coverage in PS: Political Science \& Politics. She observed that there was strong committee consensus for more extensive treatment of this subject. There had been limited attention to an e-journal, open access would be very costly despite the intellectual arguments in favor, and, drawing from other disciplinary scholarly journals, there were other ways of thinking about prepublication peer review.

Jenny Mansbridge thanked Jennifer Hochschild and the committee for their immense amount of work and hoped the discussion could focus on a review of the recommendations and their economic implications. A motion and second to that effect led to more general council discussion. Initial observations noted the richness of the report, but the need for more details on what the association wants, the costs, and the priorities. In response, several other council members queried what the committee's priorities were among the recommendations; Jennifer Hochschild responded that there was no deliberate discussion of priorities. Among the twelve members of the committee, there were selective commitments, and the two things that drew the most committee consensus were the need for current journals to have greater public engagement and, as an "impressionistic view," more exposure to research on teaching and learning. While the committee was appreciative of coverage in $P S$, it was felt the coverage needed to "go deeper." On the issue of recommendations with likely costs, one council member noted that any new publication would take significant investment likely requiring higher dues or a redistribution of current resources and that the Ralph Bunche Summer Institute should be regarded as a higher priority to be put on sound financial footing.

One council member indicated a wariness of creating another committee with a comparably broad charge (the association already has a committee looking at dissemination/ engagement and the Publications Committee would seem the likely venue for any followup of the Publications Planning report). In that same context, it was felt that $P S$ is widely read, there may be some positive aspects to moving the editorship out of the APSA office to a university, but "let's not break it up willy-nilly." In that connection, one member observed that the report did not commit the association to any particular course of action and that publishing the report would allow the entire membership to focus on the recommendations. Another member referred to the Planning Committee's conclusion that the current set of journals were not in disarray and that the association had to give thought to what our role was-you can have a lively community outside APSA jurisdiction. In that connection, another member noted that even if we can't control a new outside generation of information, we do have to be conscious that maybe these new sources are diverting membership away from the association-how do we relate to these sources in support of retaining membership? Is this a case of six solutions in search of a problem added another member? Maybe we need a strategic plan because APSA does not appear to have a vision-a common ground of understanding

The discussion then returned to the issue of PS. It had become an issue, noted one member, primarily because Rob Hauck had created the journal over twenty-plus years of editorship. Is this a case of institution building? The future of $P S$ needs to be handled right away and apart from the broader Planning Committee report, added another member. One problem was that the council members served only two years and as these issues are carried forward over time, we lose institutional memory. In that context, it was suggested that the committee's recommendations need to be disaggregated and that recommendations dealt with by appropriate standing committees. President Mansbridge asked where the issues (e.g. future of $P S$, open access, peer review, registration 
standards, and strategic planning) should be delegated. President-elect John Aldrich concurred and added that the council needed to move quickly on the issue of $P S$ on such questions of whether the editor should continue to be drawn from the APSA staff. On that point, it was suggested that perhaps an ad hoc committee on PS be created to include Rob Hauck, a representative from the Teaching and Learning Committee, a Publications Committee representative, and another appointed by the new Executive Director Steve Smith and to deliver a report in early 2014.

A motion was made and seconded by Mansbridge, of APSA, "In consultation with the Executive Director, should appoint an ad hoc committee with a report ready by the next April 2014 council meeting, and that the council should direct the Executive Director to appoint an interim editor of $P S$ following Rob Hauck's retirement." The motion passed unanimously.

Another motion was made and seconded that the Hochschild Publications Planning Committee report be accepted with its range of important issues for further discussion. The motion was passed unanimously.

\section{GOVERNANCE REFORM}

President Mansbridge began by urging council members to share any discussion over e-mail rather than in session in the interests of time.

Steven Smith said that Michael Brintnall had written an incisive memo on governance in October of 2012, and encouraged all council members to read it. He then outlined a process by which to tackle governance reform. David Lake was consulted, and he wrote a memo of the process by which the association takes up governance reform. Smith also raised the question of whether or not APSA was in compliance with District law, and whether it needed to re-incorporate. Brintnall and Chavis clarified that this was not the case. But, Steven Smith noted, there may still be practices we want to update, and noted the rapidly changing environment in which associations work.

The reform process would be a 3-year, deliberative and consultative process. What is on the table now is a vote to create an ad hoc committee on governance reform. It would be an advantage to the association if council member David Lake would be able to serve on the committee.

Jeff Isaac moved to bring the motion to a vote. Jonathan Benjamin-Alvarado, seconded. Mansbridge asked for any questions, there were none.

The motion passed via unanimous voice vote.

\section{MEMBERSHIP REPORT}

Liane Pinero-Kluge introduced herself and presented the membership report. She prefaced her report by saying she had only had 14 days in which to prepare it. As both Sean Twombly and Kathy Lamb reported before her, the membership is structured on a month-to-month basis, and the association has slowly been losing members. In 2013, APSA averaged 12,739 members each month. In 2007, it was 14,067 , and she was led to believe that before that it was closer to 15,000 on average. Earlier, Kathleen Thelen had asked a question about finances and the impact of dwindling membership; Kluge pointed out that the loss of revenue has been offset by a subtle increase in dues over time, and that has served to blunt the impact.

Kluge posed the question of how the association can sustain itself financially over time? Without repeating her report, there are many aspects in the APSA portfolio which are not being leveraged to recruit, and more importantly retain, membership.

From pulling APSA's 99os it is possible to identify 2007 revenue from membership at $\$ 1.8$ million. Kluge would argue that the key question now is what do members want? When was the last member survey done? Subsets have been done, but she is not sure when a comprehensive survey was last done.

Further, a strategic plan would provide council and staff some kind of framework going forward. That would make it possible to answer questions such as whether or not APSA is doing its best by younger faculty, research, and teaching staff, and by having a sense of what members value, and how APSA can improve and generate non-dues revenue.

Thelen asked if the dues went up incrementally for some membership categories but not others. Chavis responded that there are 2-3 categories of members where dues increases of $\$ 1$ were applied in order to not penalize members during the recession.

Kluge continued discussion about what the members might want and the value proposition of the association, and how it would be very easy to justify a $3 \%$ dues increase with a clearer value proposition.

Smith noted that there is a plan to do a member survey in the fall; once it was agreed by staff it will be circulated to council. There will be collaboration in office, and will be sent to council.

Anne Marie Slaughter stated she did want to hear about how to reach out to similar faculty associations. Everyone used to connect through associations. What about looking at cross-member societies, or exchange memberships? Brintnall responded that APSA already offers discounted memberships with for instance AHA, ASA, etc.

Brian Crisp suggested it would be useful to survey non-members as well. Brintnall agreed, though he added that non-members are no longer based in academe and are harder to locate.

Angie Wilson urged including demographic info to see if there are any trends among members who dropped off/who have left the profession, including information such as sexuality.

Kluge responded that she had pulled lapsed membership but that a lot of that demographic data is not always captured.

Wilson noted that IR students go to ISA.

Taeku Lee asked about the loss of institutional membership, which appeared to have a larger drop off. Kluge clarified that that membership is renewed annually in June, and the association was still collecting those dues. Lee agreed and noted the caveat in the report. Smith noted that Lee's point is very important, as is departmental membership.

Todd Shaw noted the irony that membership is declining even though conference attendance appears to be rising. Brintnall noted that this was familiar for other associations, where conference attendance far exceeded membership.

Paul Gronke said that Sean Twombly's earlier report on churn is important, and also noted the Chronicle article on associations that came out last spring and had previously been shared with the council.

Lake noted that there is variation in the membership regarding the meeting. If one wants to increase membership, an increase in the size of the conference is one easy way to do that. But that is something the council has been against in the past. So perhaps it is not the most important thing.

Kluge noted she wouldn't even necessarily advise increasing the size of the meeting. In her previous experience, they did a much better job of retention even when (institutional) dues rates were much higher. And there many of the same issues were present, but the retention rate was better.

Mansbridge asked if there were any more questions and concluded the discussion. 
MEMBER COMMUNICATIONS AD HOC COMMITTEE

John Aldrich noted that Mansbridge had appointed an ad hoc committee on member communications he had worked with, and there were focus groups here at the meeting, including on the new website, that were going on. Also that the current web page foundation was now being upgraded (both the AMS and CMS).

Polly Karpowicz provided a brief presentation on the upgrade and noted the change in the website. Karpowicz emphasized that it was only the 'skin' and not the content that had changed, and that this was part of a need to create new pathways for connecting and communicating. The committee will have 13 focus groups on Friday. One will be a group of committee chairs. An online survey that is out in the field should have gone out to 3,00o people by tomorrow. At this point they are collecting feedback and asked the council to stop by.

Karpowicz urged council members to come by one of the focus groups if they had a moment and asked for any questions. There were none.

Phase 2 is to upgrade the technology. Two things were critically needed-an updated content management system (CMS) and the account management system (AMS). The CMS would have to happen first since it's a legacy one.

Mansbridge thanked Karpowicz for her report and asked for the co-chairs to report.

\section{ANNUAL MEETING UPDATE}

Archon Fung said they had hoped to put together a theme and plenary that was of interest and that was publicly relevant. Cathy Boone noted that Fung had done an excellent job. The council expressed its appreciation for their work.

Mansbridge asked Kim Mealy to provide a presentation on RBSI. Mealy thanked Mansbridge and noted that the report provides an overview on p. 199-200 with a related report following. She summarized the alternative summer institute arrangements that APSA assisted with planning, placing would-be RBSI students at Texas A\&M University, University of North Texas (UNT), and Maryland. John Ishiyama was particularly instrumental in the efforts at UNT, and Mealy thanked the departments that participated. She also reached out to all the $\mathrm{PhD}$ sponsor institutions, and wanted to recognize the 14 students who would have participated in RBSI were at the meeting as part of the MSRP programs.
Mealy noted that the funding from the $\mathrm{NSF}$ used to be at $\$ 135 \mathrm{k}$ and they are now starting to look closely at a plan to fund an endowment drawing on (1) funding from foundations and (2) RBSI alums who are willing to be on the front lines. The underlying goals are to reach $\$ 3$ million with a members and friends target campaign of reaching \$250,00o to kick off, and this was being started at the annual meeting. She also noted that the Presage-Fenno fund had already collected $\$ 4,800$ and there is definitely interest in the initiative. Mealy thanked the council for their attention and welcomed any questions.

Ange-Marie Hancock prefaced he question by saying that one of her research lines is on communities of color. She asked if the individual levels are set for giving, and if not why? She also asked about appeals to the foundations and if the fundraising logistics were in place, whether key messages were ready and if they included videos of RBSI alums. She urged the preparation of these products.

Mealy answered that basically there was a preliminary structure in place, and the main effort was to make it known that this issue [RBSI funding] was a priority.

Kathleen Thelen noted that everybody loves the RBSI program, and that there are high hopes for the fund but there is a shortterm issue. She put forward a motion to the council to guarantee RBSI funding in the short term until the endowment is in place. That would send a strong statement to the community and is one of the most important things to do.

Angelia Wilson seconded the motion.

Nancy Hirschmann asked if we are committing the association to something it can't do.

Michael Brintnall noted that part of the commitment is to time and dollars for building the endowment. There are some resources within APSA, including the Centennial Center/2nd Century Fund which could support the RBSI for a period of time, plus there is the possibility of deficit funding which could be used before it becomes too painful.

Jeff Isaac asked if this was intended to be a supporting statement for Thelen's motion. Brintnall responded that it was. John Ishiyama asked if RBSI was putting in for NSF REU funding this year. Mealy responded it was. Michael Brintnall agreed, but said it was more complicated than that because RBSI had been turned down by that funding stream twice already. Perhaps RBSI could be packaged to make it more appealing to such a fund.

Hancock recommended putting a proposal for the Ford Foundation. Stephen Walt said APSA may also want to approach OSI. Mealy responded both were on the list. Hancock said that APSA had initiated lots of fundraising appeals in the past, and it had petered out, so this created a pressure to succeed early. If APSA acted as a guarantor for the RBSI as Thelen proposed, then next year, with the meeting in Washington, DC, the council might not have to have the conversation about how it hasn't raised the money.

Jeff Isaac called the motion to a vote. Mansbridge asked for a vote. The council approved the motion via a unanimous voice vote.

\section{CENTENNIAL CENTER PROGRAMS}

Mansbridge moved the discussion to the Centennial Center. Brintnall said that the Centennial Center was funded by individual donations and from gifts, and it rented space in the APSA headquarters from using money from the 2nd Century Fund. Brintnall further said that he had the opportunity to create an income stream for APSA by renting more space in the building. He reviewed the changes implemented over the summer in APSA headquarters space and noted that for at least a year there is a new rental revenue stream which has freed up the 2nd Century Funds, which could be used towards RBSI or another purpose.

Hirschman, as chair of the Centennial Center Advisory Board, stated the committee was now thinking through what do to with the new funding. The three new ideas from the board included (1) RBSI purposes/ goals paired with the Centennial Center facilities, (2) help with colleagues who are collaborating from different places to get real face time with each other, and (3) fund graduate students for internships in Washington, DC.

Brintnall said that the money is in the budget for next year, and noted that Jeff Biggs had prepared an informative memo on the history of the Centennial Center for the council.

Ishiyama asked if anything needed to be decided? Michael Brintnall responded that the council needed to be aware that there might be some competition for where the $\$ 6$ ok goes within the organization. Steven Smith added that there may be some issues around donor intent. Wildavsky's family had supported this fund with intent for a room to be available in his name, and it was important to be conscious of that. 


\section{ADVOCACY UPDATE}

Jen Diascro noted her memo to the council was longer but wanted to focus on the Coburn issue. APSA had retained the services of a lobbying firm and there did appear to be some benefits of that in that the Coburn language was not in the FY2014. It is a "clean bill" which is good but needs to have an eye kept on it. Diascro explained how the whole SBE community had also been going to bat for political scientists on the issue. In terms of the long term agenda, it is important to work with partners such as the AAAS, build relationships, reach out to university presidents, and see how things shape up. She also said the new APSA advocacy page that had gone up, and they were getting more information from those who had received NSF grants.

Gretchen Caspar wished Jen Diascro good luck in the continued efforts.

Todd Show asked a question about website links which Diascro answered, and discussion concluded.

\section{RALPH BUNCHE SUMMER} INSTITUTE

Mealy referenced the memo from Rachel Mosher-Williams, a part-time development consultant who APSA has hired. Mealy reported that there are three main areas of activity and effort since the spring meeting: (1) the canceling of the program, (2) securing for 2014, (3)long-term funding.

On canceling the program, she said that they have worked on finding alternate activities for the students and were able to secure placements for six students in research programs. They have been invited to discuss their experience here at the meeting and are presenting at a roundtable on Saturday.

She further said they reached out to $\mathrm{PhD}$ granting programs and asked if they would like to host a student. They were able to place 14 students. They also invited students to participate in other MSRP programs.

Regarding 2014 plans, APSA is working to ensure funding for it to happen at Duke University and working to find grant options. She is sending out a letter of inquiries and fall deadlines while also accessing feasibility of funding. NSF secured $\$ 135$, ooo so that is our goal. The total cost is $\$ \mathbf{2 5 0}-300 \mathrm{~K}$ with Duke and APSA helping to cover the remaining amount. In the past, we have relied heavily on foundations such as Mellon and Ford. Also departments that have sponsored it in the past have assisted financially and received some of the alumni as professors. Other support came from RBSI alumni.
Concerning long-term funding, in July 2013, the Council approved establishment of the endowment, to support the program as it is and any other programs that keep in with its spirit. Prior to establishment we used the RBSI committee to lay the groundwork. Our long term funding goal is \$ $\$ 3$ million. Our plan is to approach members and friends in a development campaign with a goal of \$250,000 with a formal announcement on Saturday at the RBSI coffee hour. Our remaining outreach is to friends and supporters. Proposal to foundations has already been submitted, with others to be submitted in the fall. The Prestow Sennage fund already collected $\$ 4$,8oo between April and now. Previously it only averaged $\$ 200$ during same period, which gives the campaign hope that this goal can be reached. Mealy thanked the council for their support.

Hancock asked, "Why are the donor letters not done yet or what are the levels of donations?" She suggested that in appeals to foundations, fundraising logistics, key messages should include some kind of productsa video or some product that we could use as part of the key messages.

Mealy responded that as of now this is all preliminary and the council would be brought in to submit input. The council also only approved the creation of the endowment in July, so that we have not had the time to develop a full campaign. The main effort was to make it known that it's a priority and provide ways for people to give and to consult with the RBSI committee and council on how the campaign should be outlined.

Kathleen Thelen said it's a great program. It would be good to put out strong statement that we are behind this $100 \%$. She made a motion that "APSA with high hopes for the endowment guarantees that this program continues and is stable. We are going to commit funding this at its current level until the endowment is in place."

Angelia Wilson seconded.

Hirschman asked where in the budget is it going to come from? Brintnall answered that we have unspent funds and external monies. Also have external revenue from the Centennial Center. Jeff Isaac said that this is very strong endorsement. John Ishiyama asked if RBSI applying for REU funding? Brintnall responded that the problem isn't Coburn it's that NSF declined funding twice before. Slaughter asked if we have talked to the Ford Foundation? Stephen Walt suggested talking to Open Society. Hancock reiterated her point that the pressure is to succeed early, since our other efforts have petered out.
Isaac called the motion for a vote. Mansbridge asked the council for a vote. Motion passed unanimously.

\section{WORKABLE SOLUTIONS TO ADVANCING WOMEN}

Jenny Mansbridge said that it would be best to table this for future discussion by email. Which by then we could get a cover memo from the CMOTSW.

Jonathan Benjamin-Alvarado motioned to table the discussion Seconded by Juan Carlos.

Angelia Wilson asked Mansbridge if members may e-mail her with suggestions? Mansbridge said that she could, and all questions should be sent to Jen Diascro at APSA.

Motion carried unanimously.

\section{TLC 2014}

Mealy reported that the Teaching and Learning Conference will be held on February 7-9, in Philadelphia. The theme is "Teaching Inclusively." She also said that the call for papers should open next week.

\section{MIDDLE EAST AND NORTH AFRICA WORKSHOP}

Betsy Super told the Council that she is focused on membership in our political community (peer review and publications, diversity of scholars, engaging publics, democratization of knowledge production). The MENA projects direct association resources to areas where we can help support open connected community of vibrant scholars. She referred the council to page 210 of their book which discusses the postponed workshop (moved from Cairo), February 2014 and June 2014. This year the workshop will have two oneweek periods and will use more of funds for networking. Super also reported that they are committed to the safety of the scholars and to the commitment we gave to the scholars in the region.

In terms of safety, scholars who are based in the region bring a variety of perspectives on safety and working in Cairo. We have a collaborative planning process. Lisa Anderson (American University in Cairo and our first host) was key in making a good decision on where/when we should the hold the workshop. Super said that she is currently monitoring the US State Department and staying in touch with Anderson and participants. They are considering moving the workshop to a contingent location since the primary location at American University in Cairo (July 3-10) was closed while on a trip in April to Cairo. 
Super looked at alternative locations (Jordan, though may not be a good location; Morocco is more likely) for both February/ June workshops.

Regarding regional commitments to scholarship and networking in workshops, Super reached out to a variety of regional organizations to ensure that scholars were tied into existing organizations and networks. The 2014 workshop call is out. Currently the committee is looking broadly at directions for the MENA project. She also said that they will look to reach out to Francophone scholars in the region.

\section{REPORT OF THE PRESIDENT-ELECT} that:

President-elect John Aldrich reported

- 2014 program chairs are working diligently on their theme "Politics after the Digital Revolution."

- Task Force: Skip Lupia worked to add new members to reflect concerns raised by Council. Task force is complete and will meet in pieces and will be launched at the member business meeting.

- Steve Rathgeb Smith: Work closely with Steve to help him integrate.

- Henry Brady: working with public engagement task force.

\section{EXECUTIVE DIRECTOR TRANSITION}

Jenny Mansbridge and the council then applauded Michael Brintnall for his many years of service to the association.

Michael Brintnall reminded the council to come to the All Member Business Meeting and the New Member Breakfast.

\section{RECOGNITION OF PRESIDENT}

John Aldrich commended Jenny Mansbridge for her service on the president. Council applauded.

\section{NEW BUSINESS}

No new business was brought up.

\section{ADJOURNMENT}

Council adjourned 5:15 p.m.

\section{Addendum to August 2013 Minutes}

\section{Main Points from August 27, 2013 Council Discussion of E-journal Proposal}

Kaare Strom, who chaired the Publications Committee that brought the e-journal proposal, was present via Skype to answer questions.

The discussion of the new e-journal included the following arguments:

\section{SUPPORT}

New disciplinary and scientific niche: Several council members (among others, Paul Gronke and David Lake) spoke out in favor of the new e-journal as filling an important new disciplinary and scientific niche.

- meets new trends in scientific publication

- takes advantage of technology in ways other journals do not/cannot

- new/trending format: building block mode, short digestible pieces, current pieces

- other disciplines (economics, psychology) are ahead of political science on this front

- APSA brand important

Supplemental research outlet: Some council members suggested that the e-journal would provide an important complementary research outlet.

- will be read by nonacademics as well

- timeliness (reduced R\&R) creates opportunities for assistant professors' publication needs

- how younger scholars are writing and thinking (via posters)

- improved publication process for younger scholars

- frees space for more traditional research format in current journals

- supplements (does not replace) current journals and traditional format

Representation of discipline:

- most subfields can meet short, concise requirements

- allows for more input from BA faculty

\section{OPPOSITION}

Representation of discipline: Several council members (among others, Ange-Marie Hancock, Nancy Hirschmann, Anne-Marie Slaughter, Kathleen Thelen) pointed out that the proposed format is biased toward quantitative and formal methodologies.
- although the mission statement sounds inclusive, the proposed format is not appropriate for most small- $\mathrm{N}$, qualitative, historical, interpretive, or normative theory pieces

- quantitative/formal methods already dominate APSA's flagship journal (APSR)

- to the extent that the new journal would provide an additional outlet for the work of younger scholars, it primarily benefits only one subset (those who employ quantitative methods)

- the exclusion of an article's tables, graphs and charts from the word count gives further advantage to quantitative work

Priorities and Assessment of Costs/Benefits: A number of council members drew attention to opportunity costs and other costs (e.g., Taeku Lee, Kathleen Thelen, Stephen Walt, Jeffrey Isaac)

- empirical evidence of need has not been demonstrated

- concerns about reviewer fatigue have not been addressed

- APSA's resources are not unlimited and so the resources devoted to a new journal would have to be weighted against other priorities (e.g., RBSI)

- an imbalance in APSA journals has been a source of conflict in the association earlier; desire to avoid repeat of those earlier conflicts

Process and timing: Several council members (Angelina Wilson, Ange-Marie Hancock, Stephen Walt, Anne-Marie Slaughter, Nancy Hirschmann) pointed out that it was counterproductive to consider the e-journal proposal in isolation.

- need to consider this specific proposal in connection with the Hochschild committee report [Publications Planning Committee Report (PS 47 (1): 246-56)], which was intended to provide a structure for the larger deliberation, including potential changes in other journals, particularly $P S$

- need broad consultation with the Association membership. Given the significant cost (with opportunities costs in other projects) and the potential for conflict, is this a project that a majority of members actually support?

Suggestions (from all corners):

- Think carefully about association/ discipline mission, strategy and priorities (e.g. pipeline before publication?) 
- Representational publication (\% pub for each subfield)

- Room for new format in current space?

- Think about role of nonacademic nonAPSA intellectual community

- Relationship between membership and publications

- Relationship between public engagement and publications

- Tie to vision/mission of association

- Blogs different form of communication, distinct from journal

- Think about crowdsourcing as alternative

\section{MOTION AND DISCUSSION}

Nancy Hirschmann then suggested a motion to table the proposal on two grounds: First, given the heated discussion among members of the council and the relatively even division of the number of council members on each side of the issue, it would be disruptive and damaging either to institute a new association-wide journal or to defeat it by such a slim majority, and that it was best to defer a vote. Second, because the Publications Planning Committee (the Hochschild committee) had made many recommendations, the Council had accepted that report, and many in the Council believed there was more work to be done in that regard, any specific proposal such as the e-journal should be part of a larger proposal for the future of the journal structure in APSA.

President-elect John Aldrich then proposed a friendly amendment to Hirschmann's motion that the measure be tabled only until the next council meeting in April 2014. Hirschmann did not accept the amendment on the grounds that Council would need to hear what the outcome of the Hochschild report was going to be and how the e-journal would fit into that larger plan for restructuring the journals.

Hirschmann's motion to table the issue passed, though some were opposed. Among the proposal's supporters, David Lake was against tabling the measure and favored moving forward with the e-journal proposal. Among the proposal's opponents, Angelia Wilson explained that she would oppose the motion to table the issue because she was worried that the fluidity of the Council would be used strategically to bring the issue back on the agenda as soon as the membership had changed, and that the arguments made at today's meeting would be lost.

After the vote on the Hirschmann motion, Kathleen Thelen requested a straw vote on how Council members would have voted if the e-journal proposal itself had been offered for a vote, but Michael Brintnall said this was not procedurally possible. He clarified that the procedure required in order for the e-journal to be "untabled" was a motion in a later Council meeting and a vote by the later Council to put it back on the table.

\section{Minutes of April 5, 2014, APSA Council Meeting}

\author{
Saturday, April 5, 2014 \\ Chicago, IL
}

\section{Meeting called to order at 8:30 a.m.}

\section{PRESIDENT'S WELCOME}

\section{MEMBERS PRESENT:}

President: John Aldrich; President Elect: Rodney E. Hero; Vice Presidents: Philip Keefer, J. Donald Moon, and Melissa Nobles; Treasurer: Kathleen Thelen; and Secretary: K.C.Morrison

Council Members: Amrita Basu, Kenneth R. Benoit, Gretchen G. Casper, Brian F. Crisp, Christine Di Stefano, James N. Druckman, Juan Carlos Huerta, Hank C. Jenkins-Smith (by phone), David C. Kang, Junko Kato, Joanne Miller, Todd C. Shaw, John M. Sides, Evelyn M. Simien, Kenneth D. Wald

American Political Science Review Editorin-Chief: John Ishiyama and Perspectives on Politics Editor-in-Chief: Jeffrey Isaac

AM Program Co-Chairs: Simon D. Jackman and Melanie Frances Manion

Executive Director: Steven Rathgeb Smith

APSA Staff: Regina Chavis, Jennifer Diascro, and Liane Pinero-Kluge

\section{NEXT MEETING}

APSA Annual Meeting, August 27-31, Washington, DC

\section{CONSENT AGENDA/APPROVAL OF MINUTES}

Motion to consent to meeting agenda by Steven Rathgeb Smith

- Motion passed by voice

Motion to send electronic comment on the August 2013 Council Meeting Minutes via APSA Connect with a deadline of one week to complete revisions and distribute meeting minutes for electronic approval by Juan Carlos Huerta

- Motion seconded by Kathleen Thelen

- Friendly amendment 1 proposed by Thelen to reach out to former Council members to secure context and substance of discussions previously excluded from meeting minutes

- Friendly amendment 2 proposed by Donald Moon to capture this context and substance in future meeting minutes

- Motion passed by voice

\section{PRESIDENT'S REPORT}

\section{FINANCE REPORT OF THE} TREASURER

\section{EXECUTIVE DIRECTOR'S REPORT}

\section{STATUS OF WOMEN IN THE PROFESSION COMMITTEE RECOMMENDATIONS}

Recommendations of the Committee presented by Committee representative, Jennifer Diascro, to regularly publish a mentoring column addressing issues of women in the profession, and to create a fund providing travel or other small grants to facilitate women's participation in the APSA Annual Meeting

Motion to approve the recommendations of the Committee on the Status of Women in the Profession by Huerta

- Motion seconded by Gretchen Casper

- Discussion

- Motion tabled for later discussion (See later section under "Status of Women in the Profession Committee Recommendations")

\section{PS REVIEW COMMITTEE REPORT}

Review Committee presents report to the Council

Motion to empower APSA Executive Director and APSA staff to hire a one-year interim editor for $P S$ by Jeffrey Isaac

- Motion seconded by John Ishiyama

- Friendly amendment proposed by Joanne Miller to appoint interim editor for two-year period

- Motion tabled 
Motion to accept the report and recommendations of the PS Review Committee by Isaac

- Motion seconded by Thelen

- Motion passed by voice

Motion to empower APSA Executive Director and APSA staff to hire an interim editor for $P S$ revived by Isaac

- Motion seconded by Ishiyama

- Motion passed by voice

Motion to empower APSA Executive Director Steve Rathgeb Smith and APSA President John Aldrich to form an ad-hoc committee to recommend a new structure for editorship, whether based at a university or as an APSA employee, and the future of $P S$ by Isaac

- Motion seconded by Ishiyama

- Motion passed by voice

Motion to address at the next council meeting what an appropriate model for PS would be by Isaac

- Friendly amendment proposed by John Aldrich to authorize the selection of an ad hoc committee composed of those who have already served and then fill in where needed

- Motion seconded by Ishiyama

- Discussion

- Motion passed by voice

\section{PERSPECTIVES ON POLITICS}

ANNUAL REPORT

Editor Jeffrey Isaac presents his report to the council on the status of the publication

Motion to accept the report of the Editor of Perspectives on Politics by K.C. Morrison

- Motion seconded by [not identifiable in audio]

- Motion passed by voice

\section{ANNUAL MEETING UPDATE BY} MELANIE MANION AND SIMON JACKMAN

\section{PERSPECTIVES ON POLITICS EDITOR SEARCH COMMITTEE REPORT}

Search Committee representatives present their report to the council, including their recommendation to retain Jeffrey Isaac as editor of Perspectives on Politics for an additional term

Motion to accept the Committee's report in its entirety by Miller

- Motion seconded by Huerta

- Motion passed by voice

Motion to extend the term of Jeffrey Isaac as editor of Perspectives on Politics by two years by Huerta
- Motion seconded by [not identifiable in audio]

- Discussion

- Motion passed by voice

Motion to delegate to the Publication Committee the duty of investigating the term of office of all APSA journal editors and making a recommendation to the council by Todd Shaw

- Motion seconded by Carlos Huerta

- Motion dropped

\section{STATUS OF WOMEN IN THE PROFESSION COMMITTEE RECOMMENDATIONS (RESUMED)}

Resume discussion of Motion on the floor (See section above under "Status of Women in the Profession Committee Recommendations")

- Motion passed by voice

Motion for the ED to form a sub-committee to oversee and implement recommendations of the Kristen Monroe report by Miller

- Motion seconded by Gretchen Casper

- Motion passed by voice

\section{RALPH BUNCHE SUMMER INSTITUTE: 2015 AND BEYOND}

Motion to form a working group to study the future financial and substantive options of the Ralph Bunch Summer Institute in 2015 and beyond, to include building a \$3,000,000 Ralph Bunche endowment by Miller

- Motion seconded by Morrison

- Motion passed by voice

\section{APSA TEACHING AND LEARNING CONFERENCE: 2015 AND BEYOND}

Discussion led by Steven Rathgeb Smith on the future of the Teaching and Learning Conference in its current format

Motion to form an ad hoc committee to study options for the Teaching and Learning Conference in future years by Shaw

- Motion seconded by Ishiyama

- Motion passed by voice

\section{ROBERT DAHL AWARD}

Review of previous council action on the formation of an ad hoc committee to discuss the development of a Robert Dahl Award

Motion to form ad hoc committee by Isaac

- Motion seconded by Brian Crisp

- Motion passed by voice

\section{KEN WALTZ AWARD}

Discussion about renaming the Helen Dwight Reid Award for Ken Waltz in light of the dissolution of the Helen Dwight Reid
Foundation and cessation of Foundation funding for the APSA award

Motion to discontinue the Helen Dwight Reid Award by Miller

- Motion seconded by [not identifiable in audio]

- Motion withdrawn

Discussion about sending information to Development Committee to consider

PANEL ALLOCATIONS

Discussion about history and current practice of panel allocations

Motion to evaluate the formula determining panel allocations using 2013 as a baseline while the formula proposed in August 2013 is implemented as a test in 2014 by Huerta

- Motion seconded by [not identifiable in audio]

- Motion withdrawn

Motion to task the Annual Meeting Committee with evaluating the panel allocations formula by Miller

- Motion seconded by Huerta

- Friendly amendment to consult with the Organized Section Committee in evaluating the formula by Huerta

- Motion passed by voice

\section{GOVERNANCE REFORM} COMMITTEE REPORT

Committee update by Miller, reflecting a three-year plan for reviewing and reforming the APSA Constitution and By-laws with regard to bringing them into compliance with DC non-profit laws. The first meeting of this committee will be in fall 2014.

\section{PUBLICATIONS PLANNING COMMITTEE REPORT AND E-JOURNAL}

Resume discussion of the Publications Planning Committee Report and proposed APSA e-journal, tabled from the previous APSA Council Meeting

Motion to pass the report of the Publications Planning Committee to the Publications Committee for deliberation on a set of specific recommendations based on the proposal by Miller

- Motion seconded by Huerta

- Friendly amendment that the approved report and recommendations of the $P S$ Review Committee and the initial proposal for an e-journal should accompany the report of the Publications Planning Committee to inform the recommendations of the Review Committee by Todd Shaw

- Motion passes by vote, $13-4$ 
Gazette

Motion that the Council request concrete recommendations on subdisciplinary journals by [not identifiable by audio]

- Motion seconded by [not identifiable by audio]

- Motion passed by voice

COMMITTEE NOMINATIONS

Nominations Committee results included in Council Book

LOCATION OF 2015 SPRING COUNCIL MEETING

\section{ADJOURNMENT}

Motion to adjourn by Thelen Motion passed by voice

Meeting adjourned 